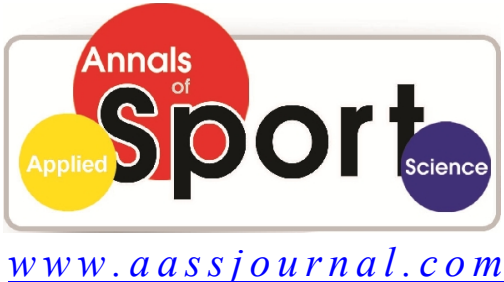

ISSN (Online): 2322 - 4479

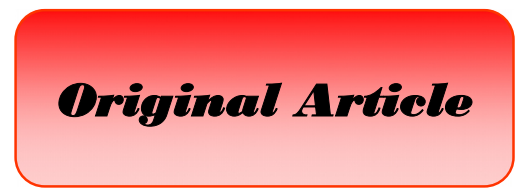

Received: 27/02/2014

Accepted: 09/05/2014

\title{
Pistacia Atlantica Extract Enhances Exercise- Mediated Improvement of Antioxidant Defense in Vistar Rats
}

\section{${ }^{1}$ Parvin Farzanegi*, ${ }^{2}$ Abbass Ghanbari-Niaki, ${ }^{1}$ Abbas Mohseni, ${ }^{1}$ Marzieh Haghayeghi}

1. Department of Exercise Physiology, Faculty of Humanities, Sari Branch, Islamic Azad University, Sari, Iran.

2. Division of Exercise Biochemistry, Faculty of Physical Education and Sports Sciences, University of Mazandaran, Babolsar, Iran.

\begin{abstract}
Exercise training causes increased oxidative stress. Pistacia Atlantica Extract (Mastic) is known to have a protective effect against oxidative stress and inflammation. We examined the effects of exercise training with and without Pistacia Atlantica extract administration on antioxidant markers in vistar rats. Twenty-eight Vistar female rats (six to eight weeks old, 150-200 g weight) allocated into training $(n=14)$ and control $(n=14)$ groups and further divided into saline + control $(n=7)$, saline + training $(n=7)$, mastic + control $(n=7)$, and mastic + raining $(n=7)$. The training groups were given exercise on a treadmill at $25 \mathrm{~m} / \mathrm{min}(0 \%$ grade $)$ for $60 \mathrm{~min} /$ day, 5 days/week for eight weeks. Mastic groups were administered at a dose $100 \mathrm{mg} / \mathrm{kg}(7.5 \mu \mathrm{L} / \mathrm{g}$ of body weight), orally. Seventy-two hours after the last training session, the rats were sacrificed and their liver tissues were excised for tissue oxidative stress markers which were detected by ELISA method. Mastic, Exercise, and Exercise+ Mastic attenuated MDA compared to control $(\mathrm{p}<0.01)$. Exercise + Mastic showed a stronger suppressive effect than Mastic and exercise. Mastic and Exercise significantly the increase in SOD compared with control $(\mathrm{p}<0.05)$. Exercise + Mastic showed further additive effects on increasing SOD $(\mathrm{p}<0.001)$. These results suggest that Mastic supplementation and exercise alone induced positive adaptations in modulating oxidant and antioxidant levels without causing the reduced/oxidized glutathione ratio (GSH/GSSG) in liver of vistar rats, but the combined intervention is more effective than either intervention alone.
\end{abstract}

Key Words: Pistacia Atlantica, Exercise Training, Oxidant and Antioxidant Enzymes.

Corresponding Author:

Parvin Farzanegi

E-mail: parvin.farzanegi@gmail.com 


\section{INTRODUCTION}

Reactive oxygen species (ROS), such as superoxide and hydroperoxyl, and reactive nitrogen species (RNS), are generated via mitochondrial oxidative process. An increase in ROS levels, oxidative stress occurs (1). There is increasing evidence that ROS in living systems damages macromolecules such as DNA, proteins and lipids (2). To protect against these radicals, body has antioxidant defense system including anti-oxidative enzymes of superoxide dismutase (SOD), catalase (CAT), glutathione peroxide (GPX) and non-enzymatic anti-oxidations such as vitamins $\mathrm{E}, \mathrm{C}, \mathrm{A}$ and flavonoids, uric acid, bilirubin, ferritin, thiols like glutathione (GSH), ubiquinone (coenzyme Q10) and micronutrients such as iron, copper, zinc, selenium, manganese (1). Imbalance between these radicals and antioxidant defense system causes oxidative stress which involves in pathogenesis of different diseases $(2,3)$. Exercise training represents a physical stress that may induce structural damage to muscle cells (4), and product of $\operatorname{ROS}(5,6)$. There is evidence that indicated increased ROS by acute intense exercise may cause an imbalance between oxidant and antioxidant systems, and the development of oxidative stress (7). Therefore, the objectives should be defined for each case, in a way that does not impair or over stimulate an immune response. Although there are clear benefits of exercise practice in diabetic patients, a detailed comprehension of the molecular basis underlying these helpful effects remains incomplete (8). Sun et al. (2010) reported that endurance training for 8 weeks increases liver tissue (GSH) (9). Hamdi (2011) observed reduction in GSH and increase in malondialdehyde (MDA) of liver tissue following exhaustive exercises (10). Previous dietary interventions with pistachios conducted in humans have shown improvements in lipoprotein profiles (11-13). Sari et al. (2010) prescribed participants pistachio diet for 4 weeks instead of saturated fat about $\% 20$ of daily caloric intake along with Mediterranean diet. Pistachio diet resulted in reduction of glucose, lipids, interleukin-6, total oxidant status and malondialdehyde and increase of superoxide dismutase (14). However, all of these studies were conducted in free-living individuals and none controlled for antioxidant content of the background diets $(15,16)$. Therefore, it is difficult to establish the extent to which pistachio-derived antioxidants contributed to the observed effects on antioxidant capacity over the displacement of saturated fat resulting from nut consumption. The present clinical study of the antioxidant effects of pistachios is unique, because it utilized a controlled-feeding crossover design and 1 dose of pistachios.

While different studies have investigated the response of liver antioxidant and antioxidant to extract and training, considerably less is known about liver adaptations after Mastic and chronic exercise training $(10,15)$. Of note, while exercise training and Mastic seems to improve oxidative modulation, endurance training challenge the body's antioxidant defenses (16). In this sense, studies aiming to identify liver mitochondria adaptations to exerciserelated oxidative stress after training and Mastic consumption are still incipient. Therefore, the aim of this study was to evaluate the impact of pistacia atlantica on rat liver mitochondria oxidative stress modulation after exercise training.

\section{MATERIALS AND METHODS}

Animals. This experiment followed the guidelines published by the Council of the Physiological Society of Mazandaran. Twenty-eight 6-8 weeks female rats weight 150-200 g were housed in a climatecontrolled laboratory animal facility at the Experimental Animal Center, Faculty of exercise physiology, Mazandaran University 
( $23 \pm 1 \mathrm{C}, 50 \pm 5 \%$ relative humidity, and $12: 12$ h light-dark period) and were fed standard rat chow and water added libitum. During the period of exercise training, described below, the animals were kept in a facility of similar conditions as described above at School of Sports Sciences, Mazandaran University. Then they randomly divided into 4 groups, each consisting of 7 rats, Saline + Training (ST), Mastic + Training (MT), Saline + Control (SC), Mastic + Control (MC).

Mastic extraction. Mastic extract was prepared as follows (17): every 10 grams of mastic fruit powder was boiled in 150 milliliter water for 45 minutes, then, when it reached the room temperature, it was passed through No. 4 Whatman filter paper twice. For every $200 \mathrm{~g}$ weight of rats, $1.5 \mathrm{ml}(7.5$ $\mu \mathrm{l} / \mathrm{g}$ body weight) of the filtered solution was fed to the rats in MC and MT groups, 5 days per week, for 4 weeks after the end of the second week, 3 hours after exercise. Meanwhile simultaneous with giving mastic extract to the mentioned groups, the same amount of saline solution was given to SC and ST groups.

Protocol. All animals were familiarized with walking on a motor-driven treadmill $(5 \%, 6.8 \mathrm{~m} / \mathrm{min}, 10 \mathrm{~min} /$ day) for 5 days. The training program considered for the two training groups included 8 weeks of endurance training ( 5 days a week and with specified intensity and duration) in the form of running on a treadmill specific for animals. After 5 days of rats' familiarity with running on a treadmill machine, the training program started as follows (18): The first week: in the first session, rats were on the treadmill with the speed of 20 meters per minute and for 20 minutes. In the fifth session, the speed was increased to 25 and practice period to 35 minutes. The second week: the speed was increased to 25 meters per minute and the sessions' duration also to 60 minutes. The third, fourth, fifth and sixth weeks: the treadmill's speed and practice period of the sessions were remained constant. The seventh and eight weeks: they were repeated with the same intensity and period of the sixth week.

Sampling. After the training period, they were anesthetized with intra-peritoneal injection of anesthetic material, a combination of ketamine $(30-50 \mathrm{mg} / \mathrm{kg})$ and xylazine $(3-5 \mathrm{mg} / \mathrm{kg}), 72$ hours after the last time training after 4 hours of fasting in order to eliminate acute effects of exercise. The liver was quickly removed, weighed, and frozen with liquid nitrogen. Samples were then stored at $-80 \mathrm{o} C$ until analysis.

Preparation of Homogenate. One gram of liver was homogenized with $5 \mathrm{ml}$ of homogenate buffer containing $20 \mathrm{mM}$ glycerophosphate, $20 \mathrm{mM} \mathrm{NaF}, 2 \mathrm{mM}$ sodium orthovanadate, $1 \mathrm{mM}$ EDTA, 0.5 $\mathrm{mM}$ phenylmethylsulfonyl fluoride (PMSF), $1 \mathrm{M}$ pepstatin, $80 \mathrm{mg} / \mathrm{l}$ trypsin inhibitor, and $100 \mathrm{mM}$ Tris-Cl, $\mathrm{pH} 7.4$, and centrifuged at $900 \mathrm{~g}$ at $4^{\circ} \mathrm{C}$ for $15 \mathrm{~min}$. The supernatants were re-centrifuged at $12,000 \mathrm{~g}$ at $4^{\circ} \mathrm{C}$ for 15 min to yield sedimented mitochondrial fraction and post-mitochondrial supernatant fraction.

Analytical Methods .To assay for GSH, a fluorometric method was used. One $\mathrm{mM}$ EDTA-50mM phosphate buffer was added to the supernatant, followed by ophthadehyde (19). After $20 \mathrm{~min}$ at room temperature, the fluorescence was measured at an excitation wavelength of $360 \mathrm{~nm}$ and emission wavelength of $460 \mathrm{~nm}$. GSSG was assayed after being pre-incubated with $\mathrm{N}$ ethylmaleimide for $20 \mathrm{~min}$ and $0.1 \mathrm{M} \mathrm{NaOH}$ was substituted for phosphate buffer. SOD activity was determined with a commercial kit based on the method of Nebot (Bioxytech SOD-525). The levels of MDA were determined with a commercial kit based on the method of Gerard-Monnier (Bioxytech MDA-586). 
Statistical Analysis. The data were expressed as mean values and their standard deviation (SD). The significance of difference between control group and mastic intake group was analyzed using t-test at $\mathrm{p}<0.05$. The variables were analyzed by twoway analysis of variance (ANOVA) with mastic intake and exercise as factors. When a significant interaction effect was found, Tukey post hoc tests were performed. When a significant mastic intake or exercise effect was found and the interaction effect was insignificant, one-way ANOVA was used to compare the means of the groups. The statistical significance level was set at $\mathrm{p}<0.05$.

\section{RESULTS}

SOD concentrations were significantly lower in the SC group compared to the other groups. Training, Mastic, and Mastic + Training were effective in increased SOD, but training and Mastic + Training had a stronger effect on liver SOD than Mastic administration alone (Figure 1).

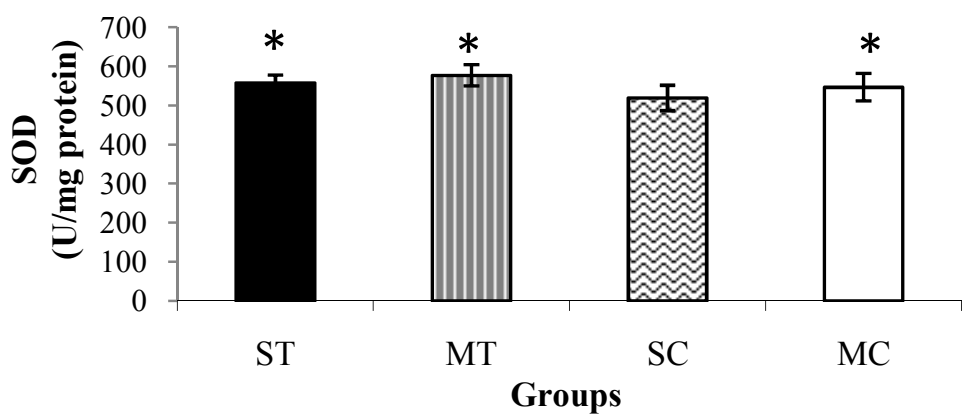

Figure 1. Liver SOD concentration. ST: Saline + Training, MT: Mastic + Training, SC: Saline + Control, MC: Mastic + Control, *: significant difference between MT with others group. The results express as mean \pm SD.

MDA concentrations were significantly higher in the SC group compared to the other groups. Training, Mastic, and Mastic + Training were effective in attenuating increased MDA, but training and Mastic + Training had a stronger suppressive effect on liver MDA than Mastic administration alone (Figure 2).

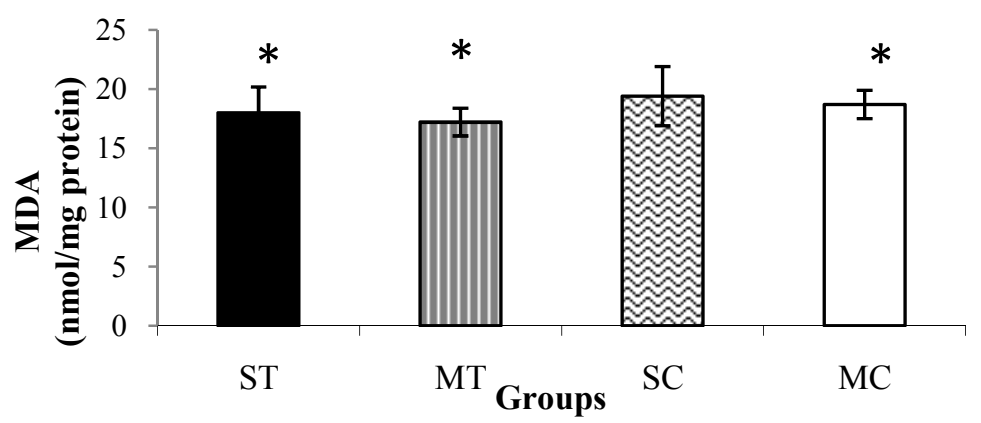

Figure 2. Liver MDA concentration. ST: Saline + Training, MT: Mastic + Training, SC: Saline + Control, MC: Mastic + Control, *: significant difference between MT with others group. The results express as mean $\pm \mathrm{SD}$. 
GSH/GSSG was unchanged in all groups. Exercise and mastic did not induce a significant increase in liver $\mathrm{GSH} / \mathrm{GSSG}$ levels (Figure 3).

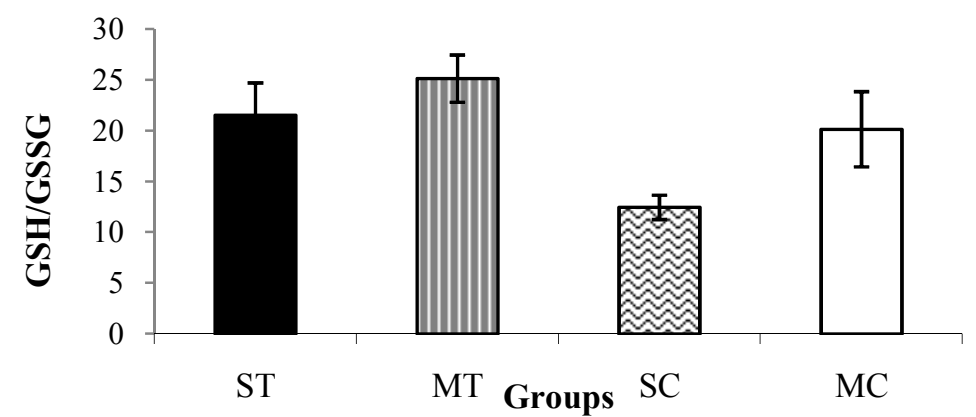

Figure 3. Liver MDA concentration. ST: Saline + Training, MT: Mastic + Training, SC: Saline + Control, MC: Mastic + Control, *: significant difference between MT with others group. The results express as mean \pm SD.

\section{DISCUSSION}

This study showed that pistacia atlantica and exercise training induced a decrease in MDA and increase in SOD and unchanged GSH/GSSG in rats. Evidence indicates a change in antioxidative enzymes resulting from exercise training which causes oxidative stress (20).

In the earlier reports, low-intensity exercise program and mastic as an antioxidant can effectively reduce oxidative stress via decrease in enzymes activities (14, 21). Our results confirmed the previous findings and indicated that, the concentration of SOD in MT group was higher than the other groups. Also there was significant difference in SOD changes between MT, ST, MC with SC group, but not observed between MT, ST, MC groups, also the training and mastic induced a significant decrease in liver mitochondrial MDA content. It is suggested that ROS production be important in the modulation of signaling pathways in the liver adaptation to training and supplement. In fact, reported to activate several signaling pathways across interactions with different molecules (22).

Although the mechanism (s) in endurance training influencing the oxidant and antioxidant indexes in female rat tissues was not clearly understood, but evidence are suggesting that the SOD activity increase and decrease MDA in liver mitochondria may be an antioxidant response to the oxidative injury caused by exercise. These findings indicate an adaptation of liver towards an enhanced antioxidant system after exercise training. In agreement to this study (19), recently it demonstrated that 8 weeks of swimming training decreased lipid peroxidation, with greater SOD enzyme activity.

Choi and Cho (2014) demonstrated exercise training $(0.5-0.8 \mathrm{~km} / \mathrm{h}, 30$ $\mathrm{min} / \mathrm{session}, 5 \mathrm{day} / \mathrm{week}$, and for 6 weeks) led to increase in Catalase, SOD activities and $\mathrm{GSH} / \mathrm{GSSG}$ ratios in trained rats, while there were no differences in MDA levels in train and control groups (23). A possible reason can be referred to for this result is the short time of training period and lack of supplementation over the training period. General belief is that regular physical exercise and supplementation cause compatibilities whose result is increase in total oxidative capacity to cope with oxidative stress. 
In the present study, liver GSH/GSSG in MT, MC, ST groups increased, but there was no statistically significant. Also a significant difference was not observed between groups. Lima et al. (2013) observed that 6-week swimming training protocol and then 3 repeated exhaustive swimming bouts with 72 $\mathrm{h}$ rest in between led to increase in reduced glutathione (GSH) content and reduced / oxidized (GSH / GSSG) ratio, SOD activity, and decreased lipid peroxidation in liver mitochondria (24). Aerobic training protected against exhaustive swimming ROS production herein characterized by decreased oxidative stress markers, higher antioxidant defenses, and increases in methyl-tetrazolium reduction and membrane potential. It seems that swimming training induced positive adaptations in liver of rats. Increased antioxidant defense after training coped with exercise-produced ROS and liver were less affected by exercise. Therefore, liver also adapt to exercise-induced ROS and may play an important role in exercise training.

In addition to exercise, the administration of Pistacia atlantica extract could suppress MDA production at a lower rate in $\mathrm{MC}$ and a greater rate in MT group compared to the control group, while exercise training program could resonate a mastic-induced suppression of MDA production. Farzanegi et al. (2013) reported that the Consumption of Pistacia atlantica extract together with endurance exercising for 8 weeks did not significantly affect glutathione peroxidase concentration, total oxidative capacity, LDL, triglyceride, or cholesterol (25).

The mechanism(s) of mastic extract in influencing the antioxidant production in female rat tissues was poorly understood. The antioxidant properties of the leaves phenolic compounds were reported. They act as a scavenger of the 1,1-diphenyl-2picrylhydrazyl (DPPH) .Also, the presence of gallic acid and its derivative, the 1, 2, 3, 4, 6-pentagalloylglucose in the fruits, play a protecting role against lipid peroxidation induced by $\mathrm{H} 2 \mathrm{O} 2$ in K562 cell line (26).

These findings confirm the antioxidant effect of exercise training and mastic. Previous studies have been controversial, and reported that exercise training and mastic might decrease antioxidant markers (27, 28). However, the antioxidant mechanism of exercise training and mastic is unclear and requires further investigations.

\section{CONCLUSION}

In summary, the present study reports that pistacia atlantica and training induces positive adaptations in liver mitochondria of rats, characterized by increases on SOD, decreases on MDA level and unchanged in GSH/GSSG ratio. On the other hand, increased antioxidant defense induced by exercise training and mastic suppress exercise-produced ROS and thus preserved liver mitochondria redox status. This data showing specific systems modulation by exercise and mastic also provide a framework to further studies aimed to examine mechanisms by which regular exercise training and mastic may alter hepatic metabolism and protect stress. Considering the importance of liver mitochondria in antioxidant defenses, it becomes clear that this organelle may play an important role in exercise training, and mastic is of interest.

\section{ACKNOWLEDGEMENTS}

All those cooperated in all phases of research implementation are appreciated.

\section{REFFRENCES}

1. Lamb RE, Goldstein BJ. Modulating an oxidative-inflammatory cascade: potential new treatment strategy for improving glucose metabolism, insulin resistance, and vascular function. International journal of clinical practice. 2008;62(7):1087-95. Epub 2008/05/21. 
2. Gupta S, Chough E, Daley J, Oates P, Tornheim K, Ruderman NB, et al. Hyperglycemia increases endothelial superoxide that impairs smooth muscle cell $\mathrm{Na}+\mathrm{K}+$-ATPase activity. American journal of physiology Cell physiology. 2002;282(3):C560-6. Epub 2002/02/08.

3. Droge W. Free radicals in the physiological control of cell function. Physiological reviews. 2002;82(1):47-95. Epub 2002/01/05.

4. Malaguti M, Angeloni C, Garatachea N, Baldini M, Leoncini E, Collado PS, et al. Sulforaphane treatment protects skeletal muscle against damage induced by exhaustive exercise in rats. Journal of applied physiology (Bethesda, Md : 1985). 2009;107(4):1028-36. Epub 2009/08/29.

5. Davies KJ, Quintanilha AT, Brooks GA, Packer L. Free radicals and tissue damage produced by exercise. Biochemical and biophysical research communications. 1982;107(4):1198-205. Epub 1982/08/31.

6. Gomez-Cabrera MC, Vina J, Ji LL. Interplay of oxidants and antioxidants during exercise: implications for muscle health. The Physician and sportsmedicine. 2009;37(4):116-23. Epub 2010/01/06.

7. Alessio HM, Hagerman AE, Fulkerson BK, Ambrose J, Rice RE, Wiley RL. Generation of reactive oxygen species after exhaustive aerobic and isometric exercise. Med Sci Sports Exerc. 2000;32(9):1576-81. Epub $2000 / 09 / 20$.

8. Timmerman KL, Flynn MG, Coen PM, Markofski MM, Pence BD. Exercise training-induced lowering of inflammatory $(\mathrm{CD} 14+\mathrm{CD} 16+)$ monocytes: a role in the anti-inflammatory influence of exercise? Journal of leukocyte biology. 2008;84(5):1271-8. Epub 2008/07/31.

9. Sun L, Shen W, Liu Z, Guan S, Liu J, Ding S. Endurance exercise causes mitochondrial and oxidative stress in rat liver: effects of a combination of mitochondrial targeting nutrients. Life sciences. 2010;86(1-2):39-44. Epub 2009/11/17.

10. Hamdi P. The effects of gender and exercise on malondialdehyde, nitric oxide and total glutathione levels in rat liver. African Journal of Pharmacy and Pharmacology. 2011;5(4):515-21.

11. Edwards K, Kwaw I, Matud J, Kurtz I. Effect of pistachio nuts on serum lipid levels in patients with moderate hypercholesterolemia. Journal of the American College of Nutrition. 1999;18(3):229-32. Epub 1999/06/22.

12. Kocyigit A, Koylu AA, Keles H. Effects of pistachio nuts consumption on plasma lipid profile and oxidative status in healthy volunteers. Nutrition, metabolism, and cardiovascular diseases : NMCD. 2006;16(3):202-9. Epub 2006/04/04.

13. Sheridan MJ, Cooper JN, Erario M, Cheifetz CE. Pistachio nut consumption and serum lipid levels. Journal of the American College of Nutrition. 2007;26(2):141-8. Epub 2007/05/31.

14. Sari I, Baltaci Y, Bagci C, Davutoglu V, Erel O, Celik H, et al. Effect of pistachio diet on lipid parameters, endothelial function, inflammation, and oxidative status: a prospective study. Nutrition (Burbank, Los Angeles County, Calif). 2010;26(4):399-404. Epub 2009/08/04.

15. Bing Y, Zhaobao W. Effects of Ginkgo biloba extract on free radical metabolism of liver in mice during endurance exercise. African journal of traditional, complementary, and alternative medicines : AJTCAM / African Networks on Ethnomedicines. 2010;7(4):291-5. Epub 2010/01/01.

16. Farzanegi P, Abdi MA, Ghanbari-Niaki A, Fathi R. Interactive effect of endurance exercise and crude alcoholic extract of magnolia on liver interleukin-6, interleukin-10, glucose, and glycogen in male rats. J Babol Univ Med Sci. 2012;14(2):22-30 [Article in Farsi].

17. Hamdan, II, Afifi FU. Studies on the in vitro and in vivo hypoglycemic activities of some medicinal plants used in treatment of diabetes in Jordanian traditional medicine. Journal of ethnopharmacology. 2004;93(1):117-21. Epub 2004/06/09.

18. Ghanbari-Niaki A, Abednazari H, Tayebi SM, Hossaini-Kakhak A, Kraemer RR. Treadmill training enhances rat agouti-related protein in plasma and reduces ghrelin levels in plasma and soleus muscle. Metabolism: clinical and experimental. 2009;58(12):1747-52. Epub 2009/07/28.

19. Ji LL, Stratman FW, Lardy HA. Antioxidant enzyme systems in rat liver and skeletal muscle. Influences of selenium deficiency, chronic training, and acute exercise. Archives of biochemistry and biophysics. 1988;263(1):150-60. Epub 1988/05/15.

20. da Cunha MJ, da Cunha AA, Ferreira AG, Machado FR, Schmitz F, Lima DD, et al. Physical exercise reverses glutamate uptake and oxidative stress effects of chronic homocysteine administration in the rat. International journal of developmental neuroscience : the official journal of the International Society for Developmental Neuroscience. 2012;30(2):69-74. Epub 2012/01/17.

21. Ghanbari-Niaki A, Rahmati-Ahmadabad S. Effects of a fixed-intensity of endurance training and pistacia atlantica supplementation on ATP-binding cassette G4 expression. Chinese medicine. 2013;8(1):23. Epub 2013/11/26. 
22. Gomez-Cabrera MC, Domenech E, Vina J. Moderate exercise is an antioxidant: upregulation of antioxidant genes by training. Free radical biology \& medicine. 2008;44(2):126-31. Epub 2008/01/15.

23. Choi EY, Cho YO. The influence of different durations of aerobic exercise on fuel utilization, lactate level and antioxidant defense system in trained rats. Nutrition research and practice. 2014;8(1):27-32. Epub 2014/03/13.

24. Lima FD, Stamm DN, Della-Pace ID, Dobrachinski F, de Carvalho NR, Royes LF, et al. Swimming training induces liver mitochondrial adaptations to oxidative stress in rats submitted to repeated exhaustive swimming bouts. PloS one. 2013;8(2):e55668. Epub 2013/02/14.

25. Farzanegi P, Mousavi M, Ghanbari-Niaki A. Effect of Pistacia Atlantica Extract on Glutathione Peroxidase Tissue Levels and Total Oxidative Capacity of Liver and Plasma Lipid Profile of Rats. 2. 2013;15(11):59-63.

26. Tomaino A, Martorana M, Arcoraci T, Monteleone D, Giovinazzo C, Saija A. Antioxidant activity and phenolic profile of pistachio (Pistacia vera L., variety Bronte) seeds and skins. Biochimie. 2010;92(9):1115-22. Epub 2010/04/15.

27. Aguilo A, Tauler P, Pilar Guix M, Villa G, Cordova A, Tur JA, et al. Effect of exercise intensity and training on antioxidants and cholesterol profile in cyclists. The Journal of nutritional biochemistry. 2003;14(6):319-25. Epub 2003/07/23.

28. Gul M, Demircan B, Taysi S, Oztasan N, Gumustekin K, Siktar E, et al. Effects of endurance training and acute exhaustive exercise on antioxidant defense mechanisms in rat heart. Comparative biochemistry and physiology Part A, Molecular \& integrative physiology. 2006;143(2):239-45. Epub 2006/01/24. 
تازههاى علوم كاربردى ورزش

\section{عصاره تَياهى آتانتيكا ييستاسيا بهبود دفاع آنتى اكسيدانى ناشى از ورزش در موشىهاى صحر ايیى را افزايش داد} 'يروين فرزانكى"*، 'عباس قنبرى نياكى، 'عباس محسنى، "مرضيه حقايقى

ا. استاديار گروه فيزيولوزى ورزشى، دانشكده علوم انسانى، دانشگاه آزاد اسلامى واحد سارى، سارى ايران.

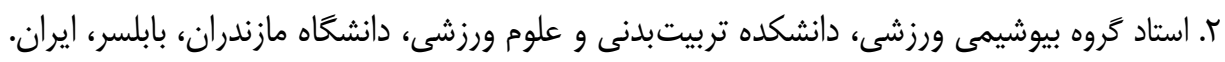
س. كارشناسى ارشد فيزيولوزى ورزشى، دانشكده علوم انسانى، دانشكاه آزاد اسلامى واحد سارى، سارى ائشى ايران.

جكيده

هدف از مطالعه حاضر بررسى اثر مصرف عصاره گياهى آتلانتيكا بيستاسيا و فعاليت ورزشى بر تعادل اكسيدانتى و آنتى اكسيدانى سطوح بافت

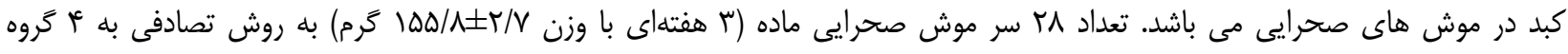

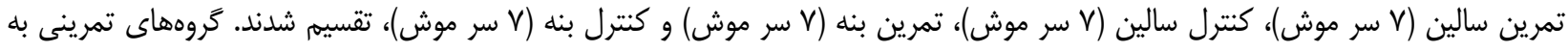

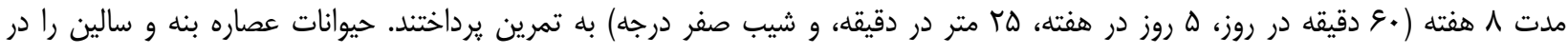

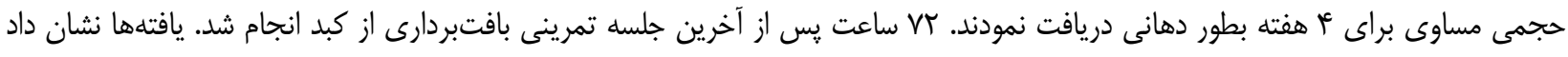

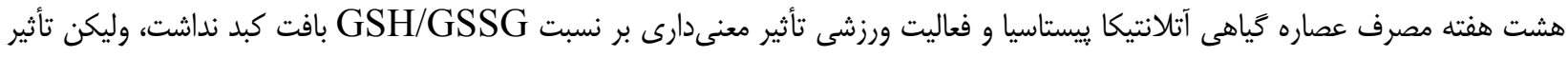

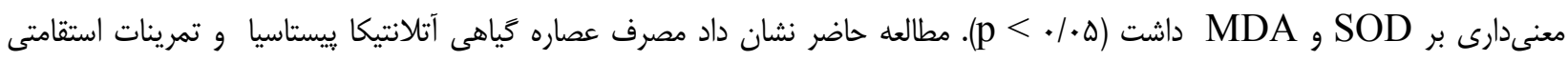

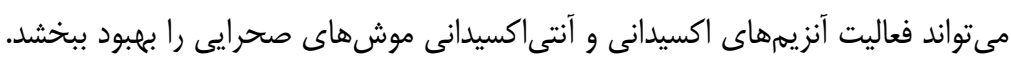
وازَّان كليدى: آتلانتيكا بيستاسيا، تمرينات استقامتى، آنزيمهاى اكسيدانى و آنتى اكسيدانى. 
